\title{
Pengaruh Fraksi Ekstrak Buah Pare (Momordica Charantia L.) Terhadap Penurunan Kadar Glukosa Darah Tikus yang Diinduksi Streptozotocin
}

\author{
Parawansah ${ }^{1,{ }^{*},}$ Rahmawati ${ }^{2}$, I Putu Sudayasa ${ }^{2}$, Andi Noor Kholidha ${ }^{3}$, Amiruddin Eso ${ }^{4}$, Nuralifah ${ }^{5}$ \\ ${ }^{1}$ Bagian Farmakologi Fakultas Kedokteran Universitas Halu Oleo \\ 2Jurusan Kedokteran \\ ${ }^{3}$ Bagian Biokimia Fakultas Kedokteran Universitas Halu Oleo \\ ${ }^{4}$ Bagian Fisiologi Fakultas Kedokteran Universitas Halu Oleo \\ ${ }^{5}$ Bagian Farmakologi Fakultas Farmasi Universitas Halu Oleo \\ Kampus Hijau Bumi Tridharma Anduonohu, Kendari 93232, Indonesia \\ *Email korespondensi : parawansah_Biom@yahoo.co.id
}

(Submit 15/03/2019, Revisi 05/09/2019, Diterima 20/12/2019)

\begin{abstract}
Abstrak
Pare adalah tanaman yang sering dimanfaatkan sebagai obat tradisional dalam menyembuhkan berbagai jenis penyakit, diantaranya diabetes mellitus. Kandungan charantine, polypeptide- $p$, vicine dan antioksidan memiliki potensi menurunkan kadar glukosa darah. Penelitian ini bertujuan untuk mengetahui aktivitas anti diabetik fraksi ekstrak buah pare dalam menurunkan kadar glukosa darah dan gambaran histopatologi jaringan pankreas tikus yang diinduksi streptozotocin. Penelitian ini menggunakan post test only control group design. Sampel penelitian ini terdiri dari 5 kelompok yaitu kelompok kontrol positif, kelompok kontrol negatif, kelompok fraksi etanol ekstrak buah pare, kelompok fraksi etil asetat ekstrak buah pare, dan kelompok n-heksan ekstrak buah pare. Pengukuran kadar glukosa darah dilakukan pada saat sebelum dilakukannya induksi STZ, setelah induksi STZ, hari ke 4 dan hari ke 7 pemberian fraksi ekstrak buah pare menggunakan glukometer dan spektrofotometer. Pada hari ke 7 dilakukan pembedahan untuk pengambilan sampel darah dan pankreas tikus. Analisis data yang digunakan adalah kruskal-wallis dilanjutkan uji mann-withney. Berdasarkan hasil penelitian, diketahui terdapat perbedaan yang signifikan antara penurunan kadar glukosa darah tikus diabetes mellitus yang diberi fraksi n-heksan ekstrak buah pare dengan kelompok kontrol negatif $(p$-value $<0,05)$. Sementara itu berdasarkan pemeriksaan histopatologi jaringan pankreas tikus yang diberi fraksi ekstrak buah pare $400 \mathrm{mg} / \mathrm{kg}$ diperoleh nilai positif ++. Terdapat aktivitas anti diabetik fraksi ekstrak buah pare dengan presentase tingkat penurunan kadar glukosa darah tikus tertinggi oleh pemberian fraksi n-heksan ekstrak buah pare $400 \mathrm{mg} / \mathrm{kg}$. Terdapat perbedaan gambaran histopatologi jaringan pankreas tikus pada kelompok yang diberi fraksi etanol, fraksi etil asetat, dan fraksi n-heksan terhadap kelompok kontrol positif dan kontrol negatif.
\end{abstract}

Kata kunci: Pare, Diabetes Mellitus, Streptozotocin. 


\section{Outline}

- Pendahuluan

- Metode

- Hasil dan Pembahasan

- Kesimpulan

- Ucapan Terima Kasih

- Daftar Pustaka

\section{Pendahuluan}

Diabetes Mellitus (DM) adalah suatu kelompok penyakit metabolik dengan karakteristik berupa hiperglikemia yang terjadi akibat kelainan sekresi insulin, kerja insulin atau kedua-duanya. Berbagai keluhan yang ditemukan pada penderita DM yaitu poliuria, polidipsi, polifagia, penurunan berat badan yang tidak dapat dijelaskan sebabnya, disertai keluhan lain berupa kesemutan, mata kabur dan lain-lain¹.

Pada tahun 2013 diperkirakan terdapat 382 juta penderita DM di dunia. Pada tahun 2035 jumlah tersebut diperkirakan akan bertambah mencapai 592 juta orang. Oleh karena itu, DM merupakan satu dari lima penyebab utama kematian di seluruh dunia. Pada tahun 2015, jumlah penderita DM di Asia Tenggara mencapai 415 juta dan diperkirakan akan mengalami peningkatan mencapai 642 juta penderita DM pada tahun $2040^{2}$.

Pengobatan penderita DM menggunakan obat sintetik harganya mahal dan memiliki efek samping yang tidak baik. Berbagai negara telah banyak melakukan pengobatan alternatif untuk berbagai penyakit termasuk DM dengan menggunakan bahan herbal ${ }^{3}$.

Plant based medicine dewasa ini digunakan di dunia sebagai terapi DM. Hal ini disebabkan karena efek sampingnya yang sedikit dan biayanya terjangkau sehingga pada negara berkembang mungkin ditetapkan sebagai pilihan utama terapi. Prinsip mekanisme kerja plant based medicine pada pasien DM yaitu regenerasi sel beta pankreas, pelepasan insulin, dan menghambat terjadinya resistensi insulin ${ }^{4}$.

Banyak tumbuhan di Indonesia yang telah terbukti dapat dimanfaatkan sebagai bahan baku anti diabetik sebab tumbuhan tersebut mempunyai senyawa yang berkhasiat menurunkan kadar glukosa darah. Pare adalah salah satu diantara 250.000 spesies tanaman obat di seluruh dunia yang diperkirakan banyak mengandung senyawa anti diabetik 5 .

Streptozotocin digunakan secara luas untuk menginduksi DM pada tikus percobaan. Mekanisme kerja STZ sebagai agen diabetogenik melalui pembentukan Reactive Oxygen Species (ROS)6. Dalam penelitian ditemukan bahwa pemberian ekstrak etanol buah pare dengan dosis $400 \mathrm{mg} / \mathrm{kg}$ pada tikus DM yang diinduksi STZ menunjukan hasil optimal dalam menurunkan kadar glukosa darah tikus hiperglikemik ${ }^{7}$. Sementara itu, pemberian ekstrak buah pare dengan dosis $200 \mathrm{mg} / \mathrm{kg}$ dan $400 \mathrm{mg} / \mathrm{kg}$ mampu meningkatkan toleransi glukosa oral pada tikus normoglikemik ${ }^{8}$. Pemberian partisi etil asetat ekstrak buah pare dengan dosis $50 \mathrm{mg} / \mathrm{kg}$ mampu menurunkan kadar glukosa darah tikus DM yang diinduksi STZ9. 
Buah pare (Momordica charantia L.) merupakan tanaman yang populer dimanfaatkan sebagai obat anti diabetik. Buah pare (Momordica charantia L.) mengandung nutrien kompleks meliputi vitamin, mineral, dan anti oksidan. Buah pare (Momordica charantia L.) memiliki kandungan utama berupa triterpenoid, proteid, steroid, alkaloid, lipid dan phenol yang berfungsi sebagai antidiabetik, serta senyawa lain berupa insulinmimetik yang memiliki efek antidiabetik ${ }^{4}$.

Berdasarkan analisis fitokimia ditemukan bahwa kandungan buah pare (Momordica charantia L.) berupa flavonoid, tanin, saponin, steroid, dan terpenoid memiliki aktivitas anti oksidan lebih tinggi dalam penangkapan radikal 1,1-diphenyl-2-picrylhidrazil (DPPH) dibanding aktivitas anti oksidan vitamin $\mathrm{E}$ dalam pelarut air maupun etanol. Buah pare (Momordica charantia L.) memiliki kandungan $\beta$-karoten lima kali lebih besar dibanding kandungan $\beta$-karoten pada wortel ${ }^{10}$.

Buah pare (Momordica charantia L.) dengan berbagai kandungan senyawa tersebut dipercaya dapat menurunkan kadar glukosa darah melalui beberapa mekanisme diantaranya melalui stimulasi penggunaan glukosa di otot skelet, menghambat pengambilan glukosa di usus, menghambat diferensiasi adiposa, dan supresi terhadap enzim yang berperan dalam proses glukoneogenesis ${ }^{4}$.

Berdasarkan uraian di atas maka peneliti tertarik untuk melakukan penelitian mengenai pengaruh fraksi ekstrak buah pare (Momordica charantia L.) terhadap penurunan kadar glukosa darah dan gambaran histopatologi jaringan pankreas tikus yang diinduksi STZ.

\section{Metode}

Penelitian ini adalah penelitian eksperimental laboratorium. Penelitian ini menggunakan post test only control group design yaitu pengaruh fraksi ekstrak buah pare (Momordica charantia L.) terhadap penurunan kadar glukosa darah dan gambaran histopatologi jaringan pankreas tikus yang diinduksi streptozotocin. Penelitian ini dilaksanakan pada bulan November- Desember 2018 bertempat di Laboratorium Terpadu Fakultas Kedokteran Universitas Halu Oleo (UHO).

Sampel penelitian ini menggunakan tikus putih jantan galur wistar (Rattus norvegicus) dengan bobot badan 150-200 gram. Penelitian ini membagi tikus menjadi 5 kelompok terdiri dari kelompok kontrol positif (glibenklamid 0,09 mg/kg), kelompok kontrol negatif ( $\mathrm{Na}-\mathrm{CMC} 0,5 \%$ ), dan 3 kelompok perlakuan (fraksi etanol, fraksi etil asetat, dan fraksi n-heksan ekstrak buah pare). Penentuan jumlah sampel tiap kelompok menggunakan rumus federer.

Pengukuran kadar glukosa darah tikus dilakukan sebelum pemberian streptozotocin (STZ) pada $h_{0}$, setelah pemberian STZ $\left(h_{1}\right)$, hari keempat $\left(h_{4}\right)$ dan hari ketujuh setelah pemberian fraksi ekstrak buah pare $\left(h_{7}\right)$. Pemberiah1n fraksi ekstrak buah pare dan glibenklamid pada tikus dilakukan melalui oral pada dan pemberian STZ dilakukan secara intraperitoneal. Pemberian sukrosa $30 \%$ dilakukan setelah pemberian STZ hingga tikus hiperglikemik. Pengukuran kadar glukosa darah tikus menggunakan glukometer easy touch pada $\mathrm{h}_{0}, \mathrm{~h}_{1}$, dan $\mathrm{h}_{4}$ dilakukan dengan cara mengambil darah di vena caudalis. Pengukuran kadar glukosa darah menggunakan spektrofotometer pada 
$\mathrm{h}_{7}$ dilakukan dengan mengambil darah dari jantung tikus setelah dianatesi menggunakan kloroform. Darah ditampung ditabung EDTA. Darah kemudian disentrifus selama 15 menit dengan kecepatan $3000 \mathrm{rpm}$ untuk mendapatkan serum. Serum tersebut ditambahkan reagen glukosa kit untuk dibaca serapannya dalam panjang gelombang $546 \mathrm{~nm}$ menggunakan spektrofotometer hingga diperoleh nilai absorbansi standar dan absoransi sampel. Rumus penentuan kadar glukosa darah tikus berdasarkan absorbansi yang dihasilkan oleh spektrofotomer:

Kadar glukosa darah $(\mathrm{mg} / \mathrm{dl})=\frac{\text { Absorbansi sampel }}{\text { Absorbansi standar }} \times 100 \mathrm{mg} / \mathrm{dl}$

Pembedahan tikus dilakukan pada $\mathrm{h}_{7}$ setelah pemberian perlakuan untuk pengambilan sampel darah serta pankreas tikus. Tikus diberi anastesi dengan kloroform. Euthanasia dilakukan dengan cara cervical dislocation berdasarkan Institutional Animal Care and Use Commite (IACUC)

\section{Hasil dan Pembahasan}

A. Pengaruh fraksi ekstrak buah pare terhadap penurunan kadar glukosa darah tikus

Tabel 1. Rerata \pm Standar Deviasi (SD) kadar glukosa darah tikus

\begin{tabular}{|c|r|r|r|r|r|r|}
\hline \multirow{2}{*}{ Waktu } & \multicolumn{1}{|c|}{$\begin{array}{c}\text { K1 } \\
\text { mean } \pm \text { SD }\end{array}$} & \multicolumn{1}{|c|}{ K2 } \\
mean \pm SD & \multicolumn{1}{|c|}{$\begin{array}{c}\text { K3 } \\
\text { mean } \pm \text { SD }\end{array}$} & \multicolumn{1}{c|}{$\begin{array}{c}\text { K4 } \\
\text { mean } \pm \text { SD }\end{array}$} & \multicolumn{1}{c|}{ mean \pm SD } \\
\hline h0 & $72,6 \pm 14,46$ & $94,2 \pm 24,29$ & $88,2 \pm 15,62$ & $97 \pm 19,96$ & $81,2 \pm 33,69$ \\
\hline h1 & $325,6 \pm 73,39$ & $189,8 \pm 66,25$ & $254,2 \pm 32,96$ & $327,2 \pm 110,92$ & $313,6 \pm 80,15$ \\
\hline h4 & $124,4 \pm 50,64$ & $348 \pm 64,52$ & $150,6 \pm 24,66$ & $393,4 \pm 85,32$ & $141,6 \pm 40,86$ \\
\hline h7 & $98,83 \pm 28,57$ & $327,4 \pm 50,16$ & $132,59 \pm 26,49$ & $121,48 \pm 20,76$ & $91,11 \pm 10,17$ \\
\hline
\end{tabular}

Keterangan :

h0 :Sebelum induksi STZ

h1 :Setelah induksi STZ

h4 :Hari ke 4 pemberian fraksi ekstrak buah pare

h7 :Hari ke 7 pemberian fraksi ekstrak buah pare

K1 :Kontrol positif (STZ 40mg/kg+glibenklamid 0,09 mg/kg)

K2 :Kontrol negatif (STZ 40mg/kg+Na-CMC 0,5\%)

K3 :Kelompok fraksi etanol ekstrak buah pare $400 \mathrm{mg} / \mathrm{kg}+\mathrm{STZ} 40 \mathrm{mg} / \mathrm{kg}$

K4 :Kelompok fraksi etil asetat ekstrak buah pare $400 \mathrm{mg} / \mathrm{kg}+\mathrm{STZ} 40 \mathrm{mg} / \mathrm{kg}$

K5 :Kelompok fraksi n-heksan ekstrak buah pare $400 \mathrm{mg} / \mathrm{kg}+\mathrm{STZ} 40 \mathrm{mg} / \mathrm{kg}$ 


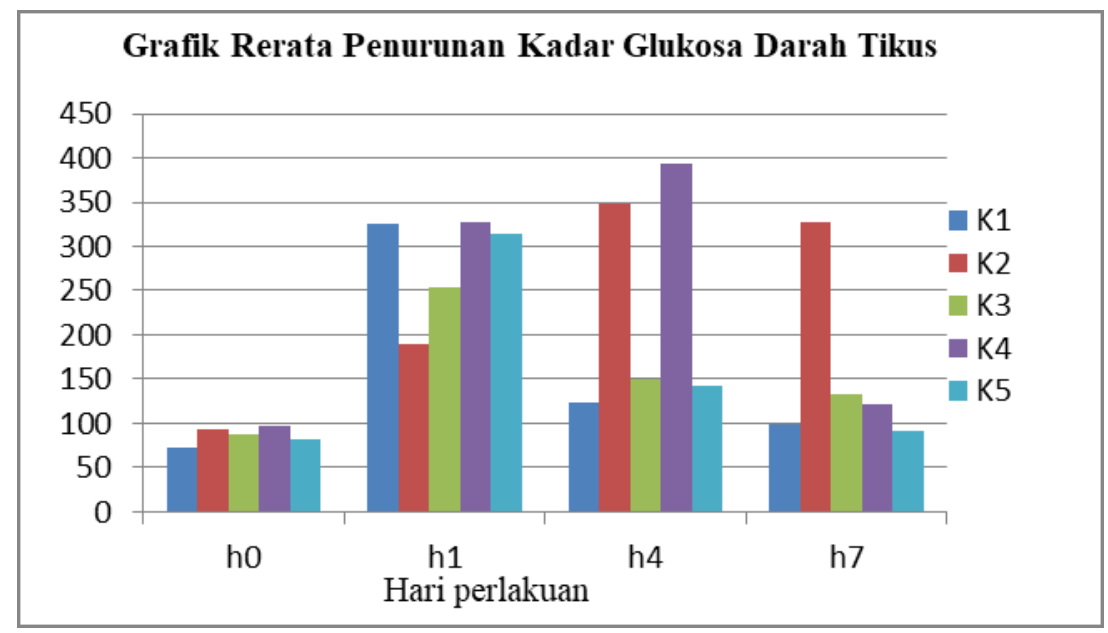

Gambar 1. Grafik rerata penurunan kadar glukosa darah tikus

Tabel 2. Uji Kruskal-Wallis nilai kadar glukosa darah tikus

\begin{tabular}{|l|r|r|r|r|} 
& \multicolumn{1}{|c|}{ h0 } & \multicolumn{1}{c|}{ h1 } & \multicolumn{1}{c|}{ h4 } & \multicolumn{1}{c|}{ h7 } \\
\hline Chi-Square & 3.438 & 10.078 & 17.115 & 15.471 \\
\hline Asymp. Sig. & .487 & .039 & .002 & .004 \\
\hline
\end{tabular}

Berdasarkan tabel 2 diketahui bahwa terdapat perbedaan secara bermakna data kadar glukosa darah tikus pada $h_{1}, h_{4}$, dan $h_{7}(p$ value $<0,05$ ) pada $K 1, K 2, K 3, K 4$, dan $K 5$, serta tidak terdapat perbedaan secara bermakna kadar glukosa darah tikus pada $h_{0}(p-$ value $>0,05)$.

Presentase penurunan kadar glukosa darah $h_{7}$ tertinggi terdapat pada kelompok fraksi n-heksan ekstrak buah pare sebesar $70,95 \%$ mendekati presentase penurunan kadar glukosa darah pada kelompok positif sebesar $69,65 \%$. Presentase penurunan kadar glukosa darah $h_{7}$ kelompok fraksi etanol ekstrak buah pare sebesar 47,84\%. Presentase penurunan kadar glukosa darah $h_{7}$ kelompok fraksi etil asetat ekstrak buah pare sebesar $62,87 \%$, sedangkan pada $h_{4}$ kelompok fraksi etil asetat belum terjadi penurunan kadar glukosa darah.

1. Gambaran Histopatologi Jaringan Pankreas Tikus

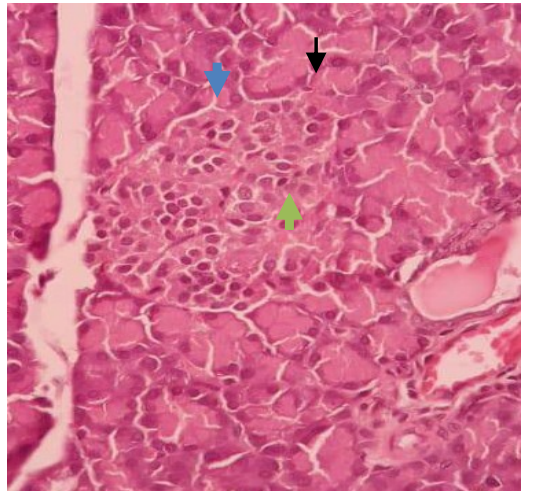

(a)

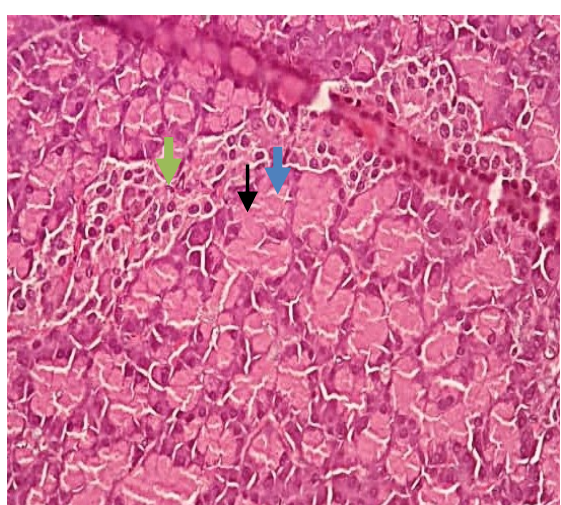

(b)

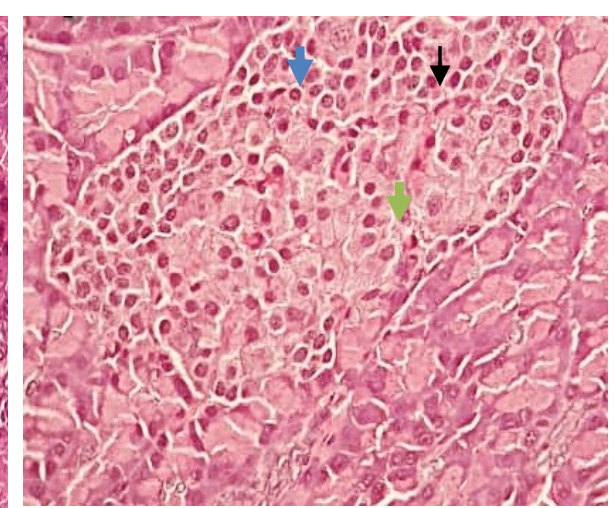

(c)

Gambar 2. Gambaran histopatologi pankreas tikus (a) K1 perbesaran 40x, sel a $(\rightarrow)$, sel $\beta(\rightarrow)$, dan sel delta $(\rightarrow)$. (b) K2 perbesaran $40 x$, sel $\alpha(\rightarrow)$, sel $\beta(\rightarrow)$, dan sel delta $(\rightarrow)$ (c) K3 perbesaran 40x sel $\alpha(\rightarrow)$, sel $\beta(\rightarrow)$, dan sel delta 
Berdasarkan gambar 2a sediaan jaringan pankreas tikus K1 (kelompok kontrol positif) menunjukkan pulau Langerhans yang terdiri dari sel a yang sitoplasmanya berglanuler serta sel $\beta$ dengan inti bulat dan sitoplasma tidak berglanular, serta sel delta yang mudah ditemukan. Berdasarkan hasil pemeriksaan histopatologi diketahui bahwa jaringan pankreas tikus dalam fungsi normal positif + .

Berdasarkan gambar $2 \mathrm{~b}$ sediaan jaringan pankreas tikus K2 (kelompok kontrol negatif) menunjukkan pulau Langerhans yang tidak terlalu jelas dengan bentuk konsentris. Pulau Langerhans terdiri dari sedikit sel $\alpha$ dengan sitoplasma berglanuler, sel $\beta$ dengan inti bulat dan sitoplasma tidak berglanular serta sel delta sulit ditemukan. Berdasarkan hasil pemeriksaan histopatologi dapat diketahui bahwa terdapat gangguan fungsi metabolik.

Berdasarkan gambar 2c sediaan jaringan pankreas tikus K3 (kelompok fraksi etanol ekstrak buah pare) menunjukkan pulau Langerhans yang terdiri dari sel a dengan sitoplasma berglanuler serta sel $\beta$ dengan inti bulat dan sitoplasma tidak berglanuler. Pulau Langerhans tersusun sangat padat dan sel delta mudah ditemukan. Berdasarkan pemeriksaan histopatologi sel penyusun pulau Langerhans pankreas diketahui bahwa jaringan pankreas tikus dalam fungsi normal positif ++ .

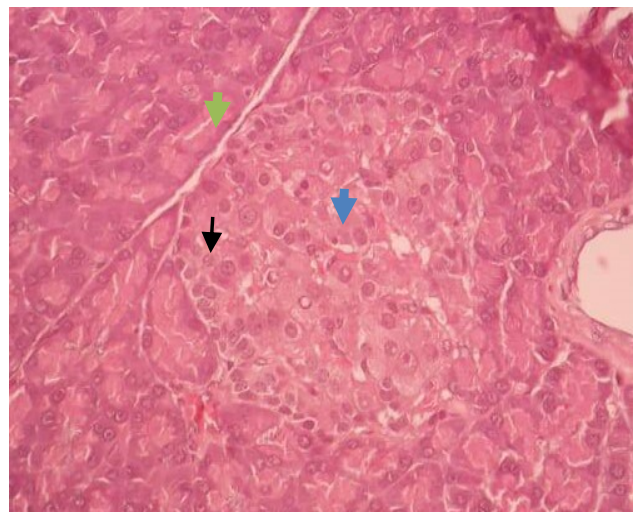

(a)

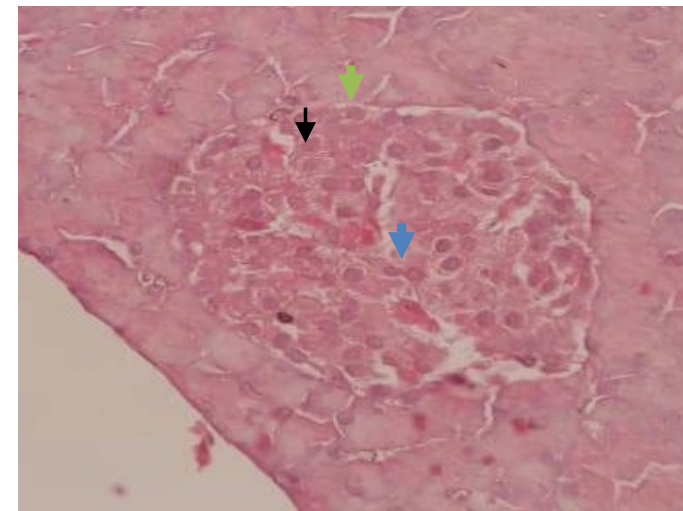

(b)

Gambar 3. Gambaran histopatologi pankreas tikus (a) K4 perbesaran 40x, sel $\alpha(\rightarrow)$, sel $\beta(\rightarrow)$, dan sel delta $(\rightarrow)$. (b) K5 perbesaran 40x, sel $\alpha(\rightarrow)$, sel $\beta(\rightarrow)$, dan sel delta $(\rightarrow)$

Berdasarkan gambar 3a sediaan jaringan pankreas tikus K4 (kelompok fraksi etil asetat ekstrak buah pare) menunjukkan pulau Langerhans yang terdiri dari sel a dengan sitoplasma berglanular dan sel $\beta$ dengan inti bulat dan sitoplasma tidak berglanular. Pulau Langerhans tersusun sangat padat dan sel delta mudah ditemukan. Berdasarkan pemeriksaan histopatologi sel- sel penyusun pulau Langerhans diketahui bahwa jaringan pankreas tikus dalam fungsi normal positif ++ .

Berdasarkan gambar 5 sediaan jaringan pankreas tikus K5 (kelompok fraksi n-heksan ekstrak buah pare) menunjukkan pulau Langerhans yang terdiri dari sel a dengan sitoplasma berglanular dan sel $\beta$ dengan inti bulat dan sitoplasma tidak berglanular. Pulau Langerhans tersusun sangat padat dan sel delta mudah ditemukan. Berdasarkan pemeriksaan histopatologi sel penyusun pulau Langerhans diketahui bahwa jaringan pankreas tikus dalam fungsi normal positif ++ . 


\section{B. Pengaruh fraksi ekstrak buah pare terhadap penurunan kadar glukosa darah tikus}

Buah pare mengandung senyawa antioksidan berupa flavonoid, dan polifenol yang dapat memperbaiki sel- sel penyusun pulau Langerhans. Flavonoid dapat menangkap radikal hidroksil yang disebabkan oleh agen diabetogenik seperti STZ ${ }^{11}$. Senyawa yang terkandung di dalam ekstrak buah pare seperti charantine, polypeptida- $p$, dan vicine mampu menurunkan kadar glukosa darah pada tikus putih diabetes mellitus melalui beberapa mekanisme diantaranya mencegah penyerapan glukosa dalam saluran pencernaan, meningkatkan penyerapan glukosa dalam jaringan, dan meningkatkan sekresi insulin ${ }^{12}$.

Fraksi etanol ekstrak buah pare mengandung anti oksidan yang dapat menurunkan kadar glukosa darah. Berdasarkan penelitian diketahui fraksi etanol ekstrak buah pare mampu menurunkan kadar glukosa darah sejak hari pertama pemberian. Nilai presentase penurunan kadar glukosa darah oleh pemberian fraksi etanol ekstrak buah pare sebesar $47,84 \%$ dibandingkan dengan presentase penurunan kadar glukosa darah dengan terapi glibenklamid sebesar $69,65 \%$. Berdasarkan penelitian yang dilakukan Mutiara dan Wildan (2014) diketahui bahwa terjadi penurunan kadar glukosa darah sebesar $50,38 \%$ oleh senyawa flavonoid yang terkandung dalam fraksi etanol ekstrak buah pare ${ }^{13}$.

Berdasarkan penelitian yang dilakukan diketahui bahwa fraksi etil asetat ekstrak buah pare $400 \mathrm{mg} / \mathrm{kg}$ mampu menurunkan kadar glukosa darah tikus diabetes mellitus setelah hari ke 4 pemberian perlakuan. Penurunan kadar glukosa darah tersebut sesuai dengan penelitian yang dilakukan oleh Ananta dkk. (2016) menunjukan bahwa terjadi penurunan kadar glukosa darah tikus diabetes mellitus setelah hari ke 4 pemberian fraksi etil asetat ekstrak buah pare $50 \mathrm{mg} / \mathrm{kg}^{9}$. Hal tersebut disebabkan oleh fraksi etil asetat menekan peningkatan kadar glukosa darah dengan cara mengaktifkan sel $\beta$ pankreas untuk produksi insulin ${ }^{14}$.

Berdasarkan hasil penelitian ditemukan fraksi n-heksan ekstrak buah pare menurunkan kadar glukosa darah secara signifikan sejak hari pertama pemberian fraksi n-heksan ekstrak buah pare pada tikus hiperglikemik. Berdasarkan penelitian yang dilakukan oleh Suartha dkk. (2016) diketahui bahwa pemberian fraksi n-heksan ekstrak buah dosis 100 $\mathrm{mg} / \mathrm{kg}$ mampu menurunkan kadar glukosa darah tikus putih ${ }^{3}$. Kandungan triterpenoid yang terkandung dalam fraksi $n$-heksan ekstrak buah pare berpotensi menurunkan kadar glukosa darah.

\section{Gambaran histopatologi jaringan pankreas tikus}

Gambaran histopatologi sel $\beta$ pada tikus normal terlihat kondisi sel- sel endokrin masih dalam keadaan utuh dan rapat ${ }^{15}$. Berdasarkan penelitian yang dilakukan oleh Baqarizky (2015) ditemukan morfologi pulau Langerhans pada kelompok yang diinduksi STZ (K2) masih dapat dibedakan dengan bagian eksokrin namun bentuk sel sulit dikenali ${ }^{16}$. Tingkat kerusakan sel $\beta$ pankreas oleh DM disebabkan oleh peningkatan radikal bebas sehingga terjadi peningkatan caspase-3 sehingga terjadi apoptosis sel. Apoptosis ini menyebabkan kerusakan sel $\beta$ berupa perubahan inti sel dan degenerasi sel ${ }^{15}$. 
Berdasarkan penelitian yang dilakukan oleh Hafizur dkk. (2011) diketahui bahwa terjadi dua kali peningkatan ukuran pulau Langerhans dan jumlah sel $\beta$ pankreas pada tikus diabetes mellitus dengan terapi ekstrak etanol buah pare dibandingkan tikus diabetes mellitus tanpa terapi. Jumlah sel $\alpha$ tidak berubah secara signifikan. Granul sekretori insulin sel $\beta$ mengalami peningkatan pada kelompok tikus diabetes mellitus dengan terapi ekstrak etanol pare ${ }^{17}$.

Terdapat mekanisme kompensasi pankreas ketika terjadi resistensi insulin melalui peningkatan ekspresi Glucagon Like Peptide-1 (GLP-1) sebagai hormon yang dihasilkan oleh sel $L$ pada saluran cerna sehingga memodulasi proliferasi serta menghambat terjadinya apoptosis sel. Modulasi proliferasi dan terhambatnya apoptosis sel dapat mempertahankan sekresi insulin sehingga menghambat perubahan bentuk sel $\beta$ pankreas. Pada tikus diabetes mellitus yang diberi terapi buah pare tetap ditemukan kerusakan sel disebabkan oleh mekanisme kompensasi pankreas yang terbantu oleh penggunaan glukosa jaringan ${ }^{18}$.

\section{Kesimpulan}

Berdasarkan hasil penelitian diketahui bahwa terdapat aktivitas anti diabetik fraksi etanol, fraksi etil asetat dan fraksi n-heksan ekstrak buah pare dengan presentase tingkat penurunan kadar glukosa darah tikus tertinggi oleh pemberian fraksi n-heksan $400 \mathrm{mg} / \mathrm{kg}$. Berdasarkan penelitian diketahui bahwa terdapat perbedaan gambaran histopatologi jaringan pankreas kelompok tikus yang diberi fraksi etanol, fraksi etil asetat, dan fraksi n-heksan terhadap gambaran histopatologi jaringan pankreas kelompok kontrol positif dan kontrol negatif.

\section{Ucapan Terima Kasih}

Terima kasih kami ucapkan kepada semua pihak yang telah terlibat dalam penelitian yang kami lakukan baik itu pihak Laboratorium Farmasi dan Laboratorium Terpadu Fakultas Kedokteran Universitas Halu Oleo, serta Laboratorium Patologi Anatomi RS. Stella Maris Makassar maupun yang terlibat dalam pengolahan data hasil penelitian.

\section{Daftar Pustaka}

1. Perkumpulan Endokrinologi Indonesia. 2015. Konsensus Pengelolaan dan Pencegahan Diabetes Melitus Tipe 2 di Indonesia. Badan Pengurus Perkeni. Jakarta.

2. International Diabetes Federation. 2013. Diabetes Atlas. Ed.6. www.idf.org/diabetesatlas. 1 Oktober 2018 (08:57).

3. Suartha, I. Nyoman., Swantara, I. Made., Rita, W. Susanah. 2016. Ekstrak Etanol dan Fraksi Heksan Buah Pare (Momordica charantia L.) Sebagai Penurun Kadar Glukosa Darah Tikus Diabetes. Jurnal Veteriner 17(1):30-36.

4. Joseph, B., Jini, D. 2013. Antidiabetic Effects of Momordica charantia (Bitter Melon) and It's Medicinal Potency. Asian Pacific Journal of Tropical Disease 3(2):93-102.

5. Achmad, A., Regar, D. Novakinanda., Harwoko. 2016. Efektivitas Ekstrak Buah Pare (Momordica charantia L.) dan Buncis (Phaseolus vulgaris) untuk Penurunan 
Kadar Gula Darah dan AUC Tikus. Pharmaceutical Journal of Indonesia 2(1):2529.

6. Szkudelski, T. 2011. The Mechanism of Alloxan and Streptozotocin Action in B Cell of the Rat Pancreas. Physiol Res. 50:536-546.

7. Parawansah, Nuralifah, Kholidha, A. Noor. 2017. Uji Anti diabetik Ekstrak Buah Pare (Momordica charantia L.) terhadap Penurunan Kadar Glukosa Darah pada Mencit yang Diinduksi Streptozotocin. Jurnal Medula 5(1):410-415.

8. Burnett, A., Mckoy, M. L., Singh, P. 2014. Investigation of the Blood Glucose Lowering Potential of the Jamaican Momordica charantia (Cerasee) Fruit in Sprague Dawley Rats. West Indian Medical Journal 64(4):315-319.

9. Ananta, M. Gufron., Suartha, I. Nyoman., Dharmayudha, A.A.G. Oka. 2016. Pengaruh Partisi Etil Asetat Ekstrak Buah Pare (Momordica charantia) terhadap Penurunan Kadar Glukosa Darah Tikus Putih (Rattus Norvegicus) yang Diinduksi Streptozotocin. Jurnal Medicus Veterinus 5(5):422-429.

10. Riyadi, N. Her., Ishartani, D., Purbasari, R. 2015. Mengangkat Potensi Pare (Momordica charantia) Menjadi Produk Pangan Olahan Sebagai Upaya Diversifikasi. Pros Sem Nas Masy Biodiv Indon 1(5):1167-1172.

11. Studiawan, H., Santosa, M.H. 2005. Uji Aktivitas Kadar Glukosa Darah Ekstrak Daun Eugenia polyanta pada mencit yang diinduksi aloksan. Media Kedokteran Hewan.

12. Alam, M. Ashraful., Uddin, R., Subhan, N., Rahman, M. Mahbubur., Jain, P., Reza, H. Mahmud. 2015. Beneficial Role of Bitter Melon Supplementation in Obesity Related Complication in Metabolic Syndrome. Journal of Lipids :1-18.

13. Mutiara, E, Verdia., Wildan, A. 2014. Ektraksi Flavonoid dari Daun Pare (Momordica charantia L.) Berbatu Gelombang Mikro sebagai Penurun Kadar Glukosa Secara In Vitro. Jurnal Metana 10(1): 1-11.

14. Padilah, 2009. Uji Hipoglikemia Fraksi Etil Asetat Biji Jinten Hitam (Nigella Sativa Linu) Pada Tikus Putih Jantan Dengan Metode Induksi Dan Toleransi Glukosa. Skripsi. Universitas Islam Negeri Syarif Hidayatullah. Jakarta.

15. Hendrawati, A. 2017. Efek Perlindungan Kombinasi Kuersetin dan Omega 3 terhadap sel $\beta$ pankreas Tikus Diabetes Mellitus Tipe 2. Pharmaciana 7(1): 1-8.

16. Baqarizky, F. 2015. Gambaran Histopatologi Pankreas, Hepar, dan Ginjal Tikus Diabetes Mellitus yang Diinduksi Streptozotocin dengan Pewarnaan Hematoksilin Eosin. Skripsi. UIN Syarif Hidayatullah. Jakarta.

17. Hafizur, R.M, dkk. 2011. Modulation of Pancreatic $\beta$ cell in Neonatally Streptozotocin Induced Type 2 Diabetic Rats by the Ethanolic Extract of Momordica charantia Fruit Pulp. Nat Prod Res 25(4): 67-353.

18. Adi, P., Soemantri, B., Darda, S., Soemantri. 2011. Efek Ekstrak Daun Pare (Momordica charantia) Terhadap Jumlah Sel $\beta$ Pankreas Tikus (Rattus norvegicus) Wistar DM Tipe 2 dengan HFD dan STZ. Thesis. Universitas Brawijaya. Malang. 